\title{
The effects of the Paleolithic Diet on obesity anthropometric measurements
}

\section{Efeito da Dieta Paleolítica em medidas antropométricas de obesos}

Nara de Andrade Parente ${ }^{2}$

(D) https://orcid.org/0000-0003-2367-9848

Helena Alves de Carvalho Sampaio ${ }^{1}$

(iD https://orcid.org/0000-0001-5353-8259

Antônio Augusto Ferreira Carioca²

(D) https://orcid.org/0000-0002-1194-562X

Filipe Oliveira Brito²

(D) https://orcid.org/0000-0002-0234-9455

Abstract - Comparing the effects of Paleolithic Diet (PD) and of a Guidelines Substantiated Diet (GSD) on anthropometric indicators of obese individuals. Randomized clinical trial. Obese patients were divided into two groups based on dietary prescription: PD and GSD. These diets encompassed 82 and 73 patients, respectively, who were followed-up for 60 days. Anthropometric measurements were taken before the beginning of the trial, at the $30^{\text {th }}$ day of it and at the end of the experimental period. At the $60^{\text {th }}$ experimental day, there was $26.8 \%$ treatment abandonment by individuals in group PD and $19.2 \%$ by the ones in group GSD; there was not difference between groups $(p=0.684)$. Weight and height measurements were taken in order to determine body mass index (BMI), waist circumference (WC) and hip circumference (HC), which allowed determining the waist/hip ratio (WHR). There was no initial difference between groups in demographic, socioeconomic, exercising and anthropometric variables ( $p$ $>0.05)$. Group PD recorded the highest weight $(\mathrm{p}=0.003), \mathrm{BMI}(\mathrm{p}=0.002)$ and WC $(\mathrm{p}$ $=0.033)$ values at the $30^{\text {th }}$ experimental day. Group PD kept the highest weight loss at the $60^{\text {th }}$ day $(\mathrm{p}<0,001)$, as well as the highest BMI $(\mathrm{p}<0.001)$, WC $(\mathrm{p}=0.002)$ and WHR ( $=0.002$ ) reduction. $\mathrm{PD}$ is a feasible option to treat obesity, it led to reduced anthropometric markers. Other studies are necessary to assure the safety of its use for longer periods of time.

Key words: Clinical Trial; Weight loss; Obesity; Waist circumference.

Resumo - Comparação do efeito da Dieta Paleolitica (DP) e da Dieta baseada em Diretrizes (DBD) em indicadores antropométricos de indivíduos obesos. Ensaio clínico randomizado. Pacientes obesos foram divididos em 2 grupos baseados na prescrição dietética: DP e DBD. Estas dietas abrageram 82 e 73 pacientes, respectivamente que foram acompanhados durante 60 dias. Medidas antropométricas foram aferidas anteriormente ao início da intervenção, no $30^{\circ}$ dia e no fim da intervenção. No $60^{\circ}$ dia de acompanhamento, houve $26,8 \%$ de desistência no grupo DP e 19,2\% no grupo DBD, não havendo diferença entre os grupos $(p=0.684)$. Peso e estatura foram aferidas para determinar o Índice de Massa Corporal (IMC), circunferência da cintura (CC), circunferência do quadril (CQ), com os quais foi determinado a relação cintura-quadril (RCQ). Nấo houve diferença estatística inicial entre os grupos nas variáveis demográficas, socioeconômicas, atividade física e antropométricas ( $p>0.05)$. O grupo DP registrou maior redução de peso $(p=0.003), I M C(p=0.002)$ e $C C(p=0.033)$ no $30^{\circ}$ dia de experimento. Grupo DP manteve maior redução de peso no $60^{\circ}$ dia $(p<0,001)$, bem como maior redução de IMC ( $p<0.001), C C(p=0.002)$ e RCQ $(p=0.002)$. DP é uma possivel opção de tratamento para a obesidade, a qual resultou na redução de marcadores antropométricos. Outros estudos são necessários para verificar seu uso por maiores periodos de tempo.

Palavras-chave: Ensaio clínico; Perda de peso, Obesidade, Circunferência da cintura.

1 Ceará State University. Postgraduation Program in Public Health. Fortaleza, CE. Brazil

2 University of Fortaleza. Fortaleza, Nutrition course. Fortaleza, CE. Brazil

Received: November 10, 2019

Accepted: January 17, 2020

How to cite this article

Parente NA, Sampaio HAC, Carioca AAF, Brito F0. The effects of the Paleolithic Diet on obesity anthropometric measurements. Rev Bras Cineantropom Desempenho Hum 2020, 22:e69957. D0l: http://dx.doi. org/10.1590/1980-0037.2020v22e69957

Copyright: This work is licensed under a Creative Commons Attribution 4.0 International License. 


\section{INTRODUCTION}

Nowadays, $65 \%$ of the world population lives in countries where obesity kills more than low weight - these countries are either of high or mid income. Mean BMI, overweight and obesity are rising worldwide on a yearly basis due to changes in dietary and exercising practices. Overweight prevalence among men and women over 18 years old reaches 39\% ${ }^{1}$.

The Brazilian scenario points towards overweight and obesity prevalence. These conditions can reach $64 \%$ and $24 \%$ of adult Brazilians, respectively ${ }^{2}$.

Accordingly, the disagreement between contemporary and paleolithic society's diet has been addressed as the possible cause of higher body weight. The paleolithic period has been shaping metabolism and physiology in the last 25 million years. Some authors believe this evolution period was not enough for humans to adapt to the contemporary diet, a fact that can suggest that the Paleolithic Diet (PD) can be excellent to prevent and treat obesity-associated metabolic disorders, type 2 diabetes mellitus (DM), heart diseases and resistance to insulin ${ }^{3}$.

The Paleolithic Diet (PD) counts on low amounts of high-glycemic index carbohydrates and only includes non-processed food. Procedures taken to food processing often imply salt addition, and it can lead to high blood pressure if salt rates in the formulas are too high. Moreover, a whole variety of vegetal oils are used in food processing, they have high omega- 6 fatty acids $(\mathrm{w}-6)$ content. These acids unbalance the $\mathrm{w}-6: \mathrm{w}-3$ ratio and it can induce chronic inflammation. The PD features have been causing some individuals to support this diet as a healthy dietary pattern, mainly to prevent and treat affections that unbalance the metabolism ${ }^{4}$.

Thus, the aim of the present study was to compare PD effects and the effects of a Guidelines Substantiated Diet by (GSD) on anthropometric indicators of obese individuals.

\section{METHOD}

A randomized clinical trial was carried out with obese patents assisted in 2017. The study has longitudinal profile and follows a quantitative approach. Patients were asked to follow one of the two diets (GSD or PD).

Sample size was determined by taking into consideration Manheimer's meta-analysis ${ }^{4}$, which aims at assessing association among 80 participants in the intervention group. The present sample counted on 181 individuals; 91 in group PD and 90 in group GSD. However, only 155 people showed up for the 30-day follow-up; 82 from group PD and 73 from group GSD. Of the total of participants in group PD, 5 did not respond to the research team's contact, 3 quitted the research because they could not follow the diet and 1 left the group because he/she underwent a bariatric surgery. In total, 9 participants in group GSD did not answer to the team's contact, 6 have reported to not being able to follow the diet and 1 was referred to assistance for food disorder since he/she needed psychological support, and 1 left the 
group because he/she underwent a bariatric surgery. The final sample counted on 155 people - the ones who followed the guidelines for at least 30 days.

The first patient was chosen by raffle. The most conventional restricted randomization method was adopted for the randomization process. It was done to assure the number of treatments presenting similarity at certain points and equally spaced from each other in the patients' attribution sequence. Randomized block randomization was used in groups with 15 participants ${ }^{5}$.

The diet substantiated by guidelines (GSD) was based on the Brazilian guidelines elaborated by the Ministry of $\mathrm{Health}^{6}$, which are in compliance with the American guidelines ${ }^{7}$ and with the Brazilian Association for Studies on Obesity and Metabolic Syndrome- $\mathrm{ABESO}^{8}$. According to these institutions, women should follow a diet with $1200 \mathrm{Kcal}$ and men should intake $1800 \mathrm{Kcal}$ a day. The proportion of macronutrients in these diets ranged from $15 \%$ to $20 \%$ of protein, from $55 \%$ to $60 \%$ of carbohydrates and from $20 \%$ to $30 \%$ of fat, respectively. Recommendations suggest 6 daily meals and provide a quali-quantitative list of replacements based on portions of food from each food group ${ }^{8}$. Breakfast must include food from the bread/cereal group and milk (and its derivatives); morning snack includes food from the fruits group; lunch includes food from groups bread/cereal, meat/eggs; legumes, vegetables; dinner includes food from groups bread/cereals, meat/egg, vegetables; and supper includes the milk/ derivatives group. Coffee and teas have no consumption limit; alcoholic drinks, sugars and sweets were excluded from the diet.

There is no single PD type; studies about food focused, or not, on this diet are quite diversified. Overall, there is no consensus about the backgrounds of this diet when it comes to other operational strategies. A menu model was elaborated based either on scientific or historical knowledge. The dietary intervention was based on a systematic review carried out by Menezes ${ }^{9}$ about the adoption of the Paleolithic Diet in intervention studies with humans. The publication by Cordain ${ }^{10}$ was consulted in order to complete information missing in articles reviewed by Menezes ${ }^{9}$. A PD model was developed and it included fruits, vegetables, white meat and beef, eggs and oilseeds; it excluded salt, sugar, sweets, processed food, refined vegetal oils, cereals, legumes, dairy products, sodas, coffee and alcoholic drinks. Olive oil, coconut oil and linseed oil were recommended for cooking. These food groups could be ingested ad libitum since $75 \%$ of publications assessed in the aforementioned literature review recommended their intake. In total, from 5 to 6 daily meals were recommended to assure adhesion to the diet. A menu based on portion sizes was not used to guide this diet, but participants were informed that they could combine the food they preferred in the list of allowed food. However, all meals should encompass food from groups fruits, vegetables, meet/egg and oilseeds.

Patients were followed-up throughout a 60-day period-of-time. Demographic and socioeconomic (sex, age, schooling, self-referred skin color, marital status and monthly family income), exercising and pre-existing disease data were collected during an interview. 
A questionnaire validated for the Brazilian population IPAQ - International Physical Activity Questionnaire was used to assessed exercising practices $^{11}$. This questionnaire classifies exercising as follows:

- Sedentary: when the individual does not exercise for at least 10 continuous minutes a week.

- Insufficiently active: it consists in classifying individuals who exercise for at least 10 continuous minutes a week, but this exercise is not enough to classify them as active. This category is divided into:

- Insufficiently Active A: individuals who exercise for at least 10 continuous minutes a week based on one of the mentioned criteria: frequency - 5 days/week or duration - 150 minutes/week;

- Insufficiently Active B: individuals who do not meet the criteria recommended for individuals in the insufficiently active A group;

- Active: individuals who meet the following recommendations: a) vigorous exercising - $\geq 3$ days/ week and 20 minutes/session; b) moderate exercising or walking $-\geq 5$ days/week and $\geq 30$ minutes/session; c) any additional exercise: $\geq 5$ days/week and $\geq 150 \mathrm{~min} / \mathrm{week}$; and

- Very Active: individuals who meet the following recommendations: vigorous $-\geq 5$ days/week and $\geq 30 \mathrm{~min} /$ session; b) vigorous $-\geq 3$ days/ week and $\geq 20 \mathrm{~min} /$ moderate session and/or walking $\geq 5$ days/week and $\geq 30 \mathrm{~min} / \mathrm{session}$.

Weight and height were used as anthropometric indicators in order to determine body mass index (BMI), waist circumference (WC) and hip circumference (HC) - the waist-hip ratio (WHR) was also calculated. Measurements were taken at the very day participants joined the research, and at the $30^{\text {th }}$ and $60^{\text {th }}$ experimental days. These data were collected by trained anthropometry professionals who were blind to the type of diet followed by the patients.

Both PD and GSD followed the protocol by Stewart ${ }^{12}$, which uses inelastic tape measure $(150 \mathrm{~cm})$. PD is measured at the point between the lower costal border $\left(10^{\text {th }} \mathrm{rib}\right)$ and the top of the iliac crest, perpendicular to the upper body. Participants must embody a relaxed posture - crossed arms over the chest - for measurement taking; they are told to breath normally. The reading is carried out at the end of a normal breath.

PD measuring takes place at the larger posterior bulge level, perpendicular to the upper body. Individuals were told to embody a relaxed posture - arms crossed over the chest, feet together and relaxed gluteus muscles - for measurement taking.

The research was designed based on Resolution 466/2012 15 and submitted to the Ethics Committee on Human Research. It was approved under Opinion 1.906.618, CAAE n. 58415016.0.0000.5534. The clinical trial was registered and published in Registro Brasileiro de Ensaios Clinicos at the website http://www.ensaiosclinicos. gov.br/, under n. RBR-5h4hht.

Participants received detailed information about the study and their participation implied signing the free and informed consent form. 
Data were analyzed in the SPSS software, version 20.0 through Chisquare test and Student's $t$ test at $\mathrm{p}<0.05$ significance level.

\section{RESULTS}

Of the 82 individuals in group PD, 67 were women (81.7\%) and 15 were men (18.3\%). Group GSD had 73 individuals; 59 were women (80.8\%) and 14 were men (19.2\%). Mean age in the PD group was $39.6 \pm 11$ years and it was $40.3 \pm 12.1$ years $(\mathrm{p}=0.701)$ in GSD.

Table 1 summarizes demographic, socioeconomic and health condition data in both groups.

Table 1. Features of patients assessed based on dietary treatment group (Paleolithic Diet - PD; Guidelines Substantiated Diet - GSD).

\begin{tabular}{|c|c|c|c|c|c|}
\hline & \multicolumn{2}{|c|}{$\mathrm{PD}(\mathrm{n}=82)$} & \multicolumn{2}{|c|}{ GSD $(n=73)$} & $p$ value \\
\hline \multicolumn{6}{|l|}{ Age group (years) } \\
\hline $18-40$ & 44 & $53.7 \%$ & 35 & $48.0 \%$ & 0.478 \\
\hline $40-60$ & 38 & $46.3 \%$ & 38 & $52.0 \%$ & \\
\hline \multicolumn{6}{|l|}{ Schooling } \\
\hline$\leq 8$ & 27 & $32.9 \%$ & 26 & $35.6 \%$ & 0.928 \\
\hline $9-11$ & 11 & $13.4 \%$ & 10 & $13.7 \%$ & \\
\hline$\geq 12$ & 44 & $53.7 \%$ & 37 & $50.7 \%$ & \\
\hline \multicolumn{6}{|l|}{ Self-referred skin color } \\
\hline White & 18 & $22 \%$ & 14 & $19.2 \%$ & 0.670 \\
\hline Non-white & 64 & $78 \%$ & 59 & $80.8 \%$ & \\
\hline \multicolumn{6}{|l|}{ Marital status } \\
\hline Married & 44 & $53.7 \%$ & 38 & $52.0 \%$ & 0.842 \\
\hline Non-married & 38 & $46.3 \%$ & 35 & $48.0 \%$ & \\
\hline \multicolumn{6}{|l|}{ Income (minimal wages ${ }^{1}$ ) } \\
\hline$\leq 1$ & 27 & $32.9 \%$ & 23 & $31.5 \%$ & 0.931 \\
\hline $1-3$ & 33 & $40.3 \%$ & 33 & $45.2 \%$ & \\
\hline $3-5$ & 17 & $20.7 \%$ & 13 & $17.8 \%$ & \\
\hline$>5$ & 5 & $6.1 \%$ & 4 & $5.5 \%$ & \\
\hline \multicolumn{6}{|l|}{ Exercising level ${ }^{2}$} \\
\hline Very Active & 2 & $2.4 \%$ & & -- & 0.289 \\
\hline Active & 34 & $41.5 \%$ & 27 & $37 \%$ & \\
\hline Insufficiently active $A$ & 19 & $23.2 \%$ & 14 & $19.2 \%$ & \\
\hline Insufficiently active B & 10 & $12.2 \%$ & 9 & $12.3 \%$ & \\
\hline Sedentary & 15 & $18.3 \%$ & 23 & $31.5 \%$ & \\
\hline \multicolumn{6}{|l|}{ Diseases $^{3}$} \\
\hline High Blood Pressure & 21 & $25.6 \%$ & 23 & $31.5 \%$ & 0.331 \\
\hline Type 2 Diabetes Mellitus & 14 & $17.1 \%$ & 11 & $15 \%$ & \\
\hline Digestive & 10 & $12.2 \%$ & 4 & $5.4 \%$ & \\
\hline Dyslipidemia & 4 & $4.9 \%$ & 8 & $11 \%$ & \\
\hline Osteoarticular & 9 & $11 \%$ & 2 & $2.7 \%$ & \\
\hline Neuropsychiatric & 6 & $7.3 \%$ & 4 & $5.5 \%$ & \\
\hline Gynecological & 2 & $2.4 \%$ & 3 & $4 . \%$ & \\
\hline
\end{tabular}

Note. 1 Minimum wage value in 2017: R\$ 937,00; 2 Investigated through the International Physical Activity Questionnaire ${ }^{13}$. Two people from group PD did not answer the question; 3 Rates do not refer to the number of participants, but to the number of mentioned diseases; it is possible having participants with more than one disease. Groups were compared based on blood pressure + diabetes mellitus $x$ other diseases. 
There was similar distribution between groups, if one takes into account the age group 40 years - older or younger. Most participants reported to have non-white skin (78\% - DP and 80.8\% - GSD) and were married (53.7\% - PD and 52.1\% - GSD). Schooling was higher than 12 years in both groups $(53.7 \%$ - PD and $50.7 \%$ - GSD). With respect to income, most participants lived on at least 3 minimum wages (73.2\% - PD and $76.7 \%$ - GSD). Most of them were insufficiently active or sedentary (53.7\% - PD and 63\% - GSD). There was no difference between groups in the investigated variables.

Of the 155 participants who have finished the 30-day follow-up - 82 from the PD groups and 73 from the GSD one -, 119 came to the 60day follow-up; 60 from the PD group and 59 from the GSD group. This outcome expresses $26.8 \%$ and $19.2 \%$ loss in each group, respectively; there was not difference between groups ( $p=0.684)$.

Among participants who have abandoned the research between the 30-day and 60-day follow-up, 10 from the PD group have returned the contact from the research team, 7 quitted the research due to personal issues, 3 stopped the diet because they got Chikungunya and 2 stopped the diet because they faced transportation issues. Of participants in the GSD group, 4 quitted their participation in the research due to personal issues, 2 did not keep the diet because they had Chikungunya and 2 faced transportation limitations.

Table 2 points out the initial anthropometric features of groups $\mathrm{PD}$ and GSD. There was no difference between groups in the assessed indicators.

Table 2. Initial anthropometric profile of the assessed participants based on dietary treatment group (Paleolithic Diet - PD; Guidelines Substantiated Diet - GSD).

\begin{tabular}{|c|c|c|c|c|c|}
\hline \multirow[b]{2}{*}{ Variable $^{1}$} & \multicolumn{2}{|c|}{$\mathrm{PD}(\mathrm{n}=82)$} & \multicolumn{2}{|c|}{$\operatorname{GSD}(n=73)$} & \multirow[b]{2}{*}{$p$ value } \\
\hline & Mean & Standard deviation & Mean & Standard deviation & \\
\hline Weight (Kg) & 91.5 & 19.97 & 88.5 & 16.44 & 0.311 \\
\hline Height (m) & 1.55 & 0.09 & 1.57 & 0.09 & 0.967 \\
\hline $\mathrm{BMI}\left(\mathrm{Kg} / \mathrm{m}^{2}\right)$ & 36.8 & 6.30 & 35.6 & 4.30 & 0.187 \\
\hline WC (cm) & 103.08 & 13.14 & 100.47 & 10.71 & 0.184 \\
\hline $\mathrm{HC}(\mathrm{cm})$ & 116.85 & 11.84 & 116.51 & 9.90 & 0.851 \\
\hline WHR & 0.89 & 0.08 & 0.87 & 0.08 & 0.145 \\
\hline
\end{tabular}

Note. $\mathrm{BMI}=$ Body Mass Index WC = Waist Circumference; $\mathrm{HC}=$ Hip Circumference $\mathrm{RCQ}=$ Waist $/$ hip ratio

Table 3 shows the evolution of anthropometric measurements in both groups at the 30-day and 60-day follow-ups. There was significant difference in weight $(\mathrm{p}=0.003), \mathrm{BMI}(\mathrm{p}=0.002)$ and $\mathrm{WC}(\mathrm{p}=0.033)$ at the 30-day follow-up; the highest lost was observed among individuals in the PD group. This group also recorded the highest weight lost at the 60-day follow-up ( $\mathrm{p}<0.001)$, as well as the highest BMI ( $<<0.001), \mathrm{WC}(\mathrm{p}=$ $0.002)$ and WHR $(\mathrm{p}=0.002)$ reduction.

Table 4 shows lower intake of energetic food in the PD group at the 30-day follow-up ( $\mathrm{p}=0.014)$ and at the 60-day follow-up ( $\mathrm{p}=0.012)$. There was difference in macronutrients consumption in both groups at the 30-day 
Table 3. Mean difference, standard deviation of anthropometric measurements of the assessed participants based on follow-up time and on dietary treatment (Paleolithic Diet - PD and Guidelines Substantiated Diet - GSD).

\begin{tabular}{lcccccc}
\hline \multirow{2}{*}{ Variable } & \multicolumn{2}{c}{30 days } & p values $^{*}$ & \multicolumn{2}{c}{60 days } & v value $^{*}$ \\
\cline { 2 - 7 } & PD $(n=82)$ & GSD $(n=73)$ & & $P D(n=60)$ & GSD $(n=59)$ & \\
\hline Weight & $-2.8 \pm 2.7$ & $-1.6 \pm 2.2$ & 0.003 & $-5.23 \pm 3.9$ & $-2.23 \pm 2.6$ & $<0.001$ \\
BMI & $-1.1 \pm 1.1$ & $-0.6 \pm 0.8$ & 0.002 & $-2.11 \pm 1.5$ & $-0.92 \pm 1.0$ & $<0.01$ \\
WC & $-3.27 \pm 3.8$ & $-1.79 \pm 4.7$ & 0.033 & $-5.5 \pm 4.8$ & $-3.0 \pm 4.0$ & 0.002 \\
HC & $-2.24 \pm 3.2$ & $-1.48 \pm 3.3$ & 0.158 & $-2.7 \pm 4.7$ & $-2.7 \pm 5.2$ & 0.981 \\
WHR & $-0.01 \pm 0.04$ & $-0.01 \pm 0.05$ & 0.321 & $-0.02 \pm 0.01$ & $0.01 \pm 0.01$ & 0.002 \\
\hline
\end{tabular}

Note. $\mathrm{BMI}=$ Body Mass Index; $\mathrm{WC}=$ Waist Circumference; $\mathrm{HC}=$ Hip Circumference; $W H R=$ Waist $/$ hip ratio

Table 4. Mean comparison of diets carried out by the assessed patients based on follow-up time and on dietary treatment group (Paleolithic Diet - PD and Guidelines Substantiated Diets - GSD).

\begin{tabular}{lcccccc}
\hline \multirow{2}{*}{ Variable } & \multicolumn{2}{c}{30 days } & \multicolumn{2}{c}{60 days } & $p_{\text {value }}^{*}$ & \multicolumn{2}{c}{} \\
\cline { 2 - 7 } & DP $(n=82)$ & DAD $(n=73)$ & & DP $(n=60)$ & DAD $(n=59)$ & \\
\hline Kcal & $1109.1 \pm 49.7$ & $1358.7 \pm 100.4$ & 0.014 & $1113.9 \pm 43.5$ & $1298.5 \pm 22.4$ & 0.012 \\
CHO & $122.8 \pm 3.7$ & $192.8 \pm 30.4$ & 0.136 & $123.8 \pm 11$ & $204.9 \pm 31.3$ & $<0.001$ \\
PTN & $79.7 \pm 1.4$ & $74.8 \pm 2.8$ & 0.256 & $75.8 \pm 0.2$ & $75.5 \pm 4$ & 0.524 \\
LIP & $35.4 \pm 2.3$ & $35 \pm 1.1$ & 0.468 & $36.7 \pm 0.6$ & $35.1 \pm 0.1$ & 0.718 \\
\hline
\end{tabular}

Note. $\mathrm{CHO}=$ Carbohydrate; PTN $=$ Protein; LIP = Lipid.

follow-up. However, based on the 60-day follow-up of the PD group, its participants ingested lower amount of carbohydrates $(\mathrm{p}<0.001)$.

\section{DISCUSSION}

Participants in the research did not differ in the assessed initial anthropometric features and markers, and it assured the quality of the randomization process. The assessed group has low family income and it can compromise their access to certain food, but it has good schooling, a fact that made it easier for participants to understand the guided diets. Insufficiently active or sedentary participants were asked to keep their shape similar to that observed at the beginning of the research. This procedure guaranteed that anthropometric results would concern the adopted diets.

In total, 155 patients participated in the research, 82 in the PD group and 73 in the GSD group - sample loss was of $26.8 \%$ and $19.2 \%$, respectively. The sample at the end of the study (119 individuals) was quantitatively robust in comparison to previous clinical trials about Paleolithic Diet published in the last few years. Similar sample losses, or even higher losses, were observed in other clinical trials with control group such as studies conducted by Jönsson's et al. ${ }^{14}$, with $23.7 \%$ of 38 individuals included for 12 weeks; Frassetto et al. ${ }^{15}$ with $41 \%$ of 32 individuals for 14 days; Mellberg et al. ${ }^{16}$ with $30 \%$ of 70 women for 24 months and Boers et al. ${ }^{3}$ with $21 \%$ of 43 participants for 2 weeks.

The PD guided in the present study stood out for having evaluated all studies that used it, as well as for having safeguarded the historical aspects of this $\operatorname{diet}^{10,17,18}$.

PD does not fit the traditional concept of healthy $\operatorname{diet}^{8}$, but it respects 
some aspects concerning the Brazilian plan for strategic actions to face Noncommunicable Chronic Diseases (NCDs), whose target is the intake of 5 or more daily portions of fruits and vegetables per $24.3 \%$ of the population by $2022^{19}$. Besides, it meets part of the current recommendations in the new food guide for the Brazilian population in comparison to the inclusion of natural food and the exclusion of processed food ${ }^{6}$.

If one compares the American recommendations to the Brazilian ones, it is possible noticing that they fit some food patterns seen as effective for weight loss, such as the suggestion for food with low sugar index, low carb diets, moderated-carb and protein diets, and high protein diets ${ }^{7}$.

There is quite big variation in follow-up time in studies about interventions based on PD, as well as on diseases reported by participants. In total, 3 clinical trials worked with 2-year follow-up in the last 5 years, this is the longest follow-up time reported in publications ${ }^{12,16}$.

A study conducted by Bisht et al. ${ }^{20}$ with 13 patients presenting multiple high school levels lasted 12 months. One study worked with 6-month duration $^{21}$ and involved post-menopause overweight women. Some studies used 3-month follow-up, such as the case of Jönsson et al. ${ }^{22}$, who worked with 13 women with type 2 diabetes mellitus; and Jönsson et al. ${ }^{14}$, who assessed 10 post-menopause healthy women for 5 weeks; Frassetto et al. ${ }^{15}$, who assessed 13 subjects with type 2 diabetes mellitus for 14 days; Boers et $\mathrm{al}^{3}{ }^{3}$, who assessed 32 people with metabolic syndrome parameters for 14 days and Masharani et al. ${ }^{23}$ who assessed 24 patients with type 2 diabetes mellitus for 14 days.

Outcomes in the present study point out greater weight loss, which has affected BMI reduction; as well as greater WC and WHR reduction among individuals in group PD. A recent systematic review with metaanalysis published by Menezes et al. ${ }^{9}$ on the effect of the Paleolithic Diet on anthropometric markers included 11 studies. It showed that PD has positive effect on weight, BMI and WC reduction.

If one takes into account studies without control group, it is possible mentioning the weight loss of $2.3 \mathrm{~kg}(\mathrm{p}<0.001)$ observed in the study by Osterdahl et al. ${ }^{24}$, who assessed the effect of this diet after 3-week followup. The study by Ryberg et al. ${ }^{25}$ aimed at assessing the Paleolithic Diet on liver and muscle fat and on insulin sensitivity by post-menopause women. This author found weight reduction of $4.5 \mathrm{Kg}(\mathrm{p}<0.01)$ after 5 -week follow-up. The study by Bisht et al. ${ }^{20}$ comprised 12-month follow-up and aimed at developing a protocol to reduce fatigue in patients with multiple schooling - he found weight loss of $7.7 \mathrm{Kg}$.

There is another meta-analysis published by Manheimer et al. ${ }^{4}$ that has assessed the effect of PD on metabolic syndrome. These authors found that WC was significantly lower in patients subjected to PD.

Waist circumference measurements were taken in only two studies. Ryberg et al. ${ }^{25}$ carried out a study without control group and found significant reduction within 5 weeks. Mellberg et al. ${ }^{16}$ detected greater WC reduction in individuals subjected to the Paleolithic Diet after 6 months. 
Besides the present research, only one study recorded WHR values of, and significant reduction in, participants under Paleolithic Diet ${ }^{25}$.

Published clinical trials are not homogeneous when it comes to diet prescribed for control groups and it impairs further comparisons. Lindeberg et al. ${ }^{26}$ and Jönsson et al. ${ }^{14}$ used a control diet based on the Mediterranean diet. Jönsson et al..$^{22}$, Frassetto et al. ${ }^{15}$ and Masharani et al. ${ }^{23}$ adopted a diet based on guidelines for individuals with diabetes. The control diet in the studies by Mellberg et al. ${ }^{16}$ followed recommendations of conventional low-fat diets (LFD), based on the Nordic Nutrition Recommendations.

Although the PD group was informed to have food intake ad libitum, individuals subjected to this diet ingested less calories than the ones on the GSD group. This outcome allowed inferring that this conduct favors adhesion. Carbohydrate content was overall lower in the Paleolithic Diet ${ }^{23}$. This outcome was observed in the current study, but differences were not significant at the $30^{\text {th }}$ experimental day. As time passed, carbohydrate reduction was more significant in the PD group. Dietary carbohydrate reduction can be the response to improvements in anthropometric markers, but still there is the need of further studies to assess such association. General aspects of diet composition and its potential effect on anthropometric indicators have been discussed by some authors, but there is no final conclusion about $\mathrm{it}^{27,28}$.

It is possible that the greatest weight loss observed in individuals subjected to PD could have resulted from greater satiety. Bligh et al. ${ }^{29}$ tested the acute effect of ingesting meals based on PD on satiety biochemical markers in comparison to diets substantiated by guidelines. There were higher Glucagon-like peptide-1 (GLP-1) and peptide YY (PYY) concentrations within 180 minutes after the use of different PD formulations.

Published clinical trials presented different anthropometric outcomes such as triglyceride levels, total cholesterol, LDL and HDL cholesterol, urinary $5-\alpha$ reductase values, systolic and diastolic blood pressure, which corroborate the positive effects of $\mathrm{PD}^{3,4,19}$.

On the other hand, although PD have had positive effects on the aforementioned clinical trials, Markofski et al. ${ }^{30}$ has called the attention to the possibility of having harming effects due to $\mathrm{PD}$, since his research showed reduced levels of Brain derived neurotrophic factor (BDNF) and serum leptin in patients subjected to it. However, his study lasted 8 weeks and only included 7 adult subjects.

The present study faced limitations similar to the ones observed in most other dietary tests, namely: lack of blindness after randomization. In order to minimize such issue, all participants were informed about the intention to compare two diets to treat obesity. Moreover, researchers who were in charge of taking the anthropometric measurements did not know the diets followed by the patients. Another limitation lies on the evaluation of the nutrition status, which was limited to anthropometric measurements. Besides, there was sample loss, although it was not attributed to diet type. On the other hand, despite the sample loss, it was not possible inferring 
significant PD effects on the assessed anthropometric markers.

It is essential extending study duration in order to confirm whether PD superiority as therapeutic strategy against obesity will be maintained. Such time-extension will allow assessing adhesion to both diet types after longer periods-of-time, as well as detecting whether there is PD use-related risk to health.

\section{CONCLUSION}

The Paleolithic Diet followed for 60 days to treat obesity led to better effects on anthropometric markers (Weight, BMI, WC and WHR) than the diet substantiated by guidelines.

\section{COMPLIANCE WITH ETHICAL STANDARDS}

\section{Funding}

This research did not receive any specific grant from funding agencies in the public, commercial, or not-for-profit sectors. This study was funded by the authors.

\section{Ethical approval}

Ethical approval was obtained from the local Human Research Ethics Committee Ceará State University and the protocol (no 1.906.618, CAAE n. 58415016.0.0000.5534) was written in accordance with the standards set by the Declaration of Helsinki.

\section{Conflict of interest statement}

The authors have no conflict of interests to declare.

\section{Author Contributions}

Conceived and designed the experiments: Sampaio HAC. Performed the experiments: Parente NA. Analyzed the data: Carioca AAF. Contributed reagents/materials/analysis tools: Brito FO. Wrote the paper: Parente NA.

\section{REFERENCES}

1. World Health Organization (WHO). Global Health Observatory (GHO) data. Overweight and obesity. 2016.

2. Brasil. Ministério Da Saúde. Instituto Brasileiro de Geografia e Estatística. Vigilância de fatores de risco e proteção para doenças crônicas por inquérito telefônico. VIGITEL. Brasília, 2019.

3. Boers I, Muskiet FAJ, Berkelaar E, Schut E, Penders R, Hoenderdos K, Wichers HJ, Jong MC. Favourable effects of consuming a Palaeolithictype diet on characteristics of the metabolic syndrome: a randomized controlled pilot-study. Lipids Health Dis 2014;13:160.

4. Manheimer EW, Van Zuuren EJ, Fedorowicz Z, Pijl H. Paleolithic nutrition for metabolic syndrome: systematic review and meta-analysis. Am J Clin Nutr 2015; 102:922-32.

5. Pocock SJ. Clinical Trials: a practical approach. John Wiley \& Sons. 1983. 
6. Brasil. Ministério Da Saúde. Secretaria de Atenção à Saúde. Departamento de Atenção Básica. Caderno de Atenção Básica: Estratégias para o cuidado da pessoa com doença crônica: Obesidade. Brasília. 2014.

7. AACE/ACE. Guidelines American Association Of Clinical Endocrinologists And American College Of Endocrinology Clinical Practice Guidelines For Comprehensive Medical Care Of Patients With Obesity. Executive Summary. 2016.

8. ABESO. Associação Brasileira para o Estudo da Obesidade e da Síndrome Metabólica. Diretrizes Brasileiras de Obesidade. 2016; 4ed - São Paulo http://www. abeso.org.br/uploads/downloads/92/57fccc403e5da.pdf Acessado em 29 de julho de 2019.

9. Menezes EVA, Sampaio HAC, Carioca AAF, Parente NA, Brito FO, Moreira TMM, Souza ACC, Arruda SPM. Influence of Paleolithic diet on anthropometric markers in chronic diseases: systematic review and meta-analysis. Nutr J. 2019;18(1):41.

10. Cordain L. Real Paleo. Fast \& Easy. Houghton Mifflin Harcourt. New York, Boston. 2015.

11. Craig CL, Marshall AL, Sjostrom M, Bauman AE, Booth ML, Ainsworth BE, Pratt M, Ekelund U, Yngve A, Sallis JF, Oja P. International physical activity questionnaire: 12-country reliability and validity. Med Sci Sports Exerc 2003; 35(8):1381-95.

12. Stewart A, Marfell-Jones M, Olds T, Ridder H. International standards for anthropometric assessment. Australia: Natinal Library of Australia. 2011.

13. Brasil. C.N. De S. Resolução No 466, De 12 De Dezembro De 2012.

14. Jönsson T, Granfeldt Y, Erlanson-Albertsson C, Ahrén B, Lindeberg S. A paleolithic diet is more satiating per calorie than a mediterranean-like diet in individuals with ischemic heart disease. Nutr Metab (Lond) 2010;7:85.

15. Frassetto LA, Shi L, Schloetter M, Sebastian A, Remer T. Established dietary estimates of net acid production do not predict measured net acid excretion in patients with Type 2 diabetes on Paleolithic-Hunter-Gatherer-type diets. Eur J Clin Nutr 2013; 67(9): 899-903.

16. Mellberg C, Sandberg S, Ryberg M, Eriksson M, Brage SC, Larsson C, Olsson T, Lindahl B. Long-term effects of a Palaeolithic-type diet in obese postmenopausal women: a 2-year randomized trial. Eur J Clin Nutr 2014;68(3):350-7.

17. Cordain L, Eaton SB, Sebastian A, Mann N, Lindeberg S, Watkins BA, O'keefe $\mathrm{JH}$, Brand-Miller J. Origins and evolution of the Western diet: health implications for the 21st century. Am J Clin Nutr 2005; 81:341-54.

18. Kuipers R, Luxwolda MF, Dijck-Brouwer DAJ, Eaton SB, Crawford MA, Cordain L, Muskiet FAJ. Estimated macronutrient and fatty acid intakes from an East African Paleolithic diet. Br J Nutr 2010;104(11):1666-87.

19. Brasil. Ministério Da Saúde. Secretaria de Vigilância em Saúde. Departamento de Análise de Situação de Saúde. Coordenação Geral de Doenças e Agravos Não Transmissíveis. Plano de ações estratégicas para o enfrentamento das doenças crônicas não transmissíveis (DCNT) no Brasil 2011-2022. Brasilia. 2011.

20. Bisht B, Darling WG, Grossmann RE, Shivapour ET, Lutgendorf SK, Snetselaar LG, et al. A Multimodal Intervention for Patients with Secondary Progressive Multiple Sclerosis: Feasibility and Effect on Fatigue. J Altern Complement Med 2014;20(5):347-55.

21. Blomquist C, Chorell E, Ryberg M, Mellberg C, Worrsjö E, Makoveichuk E, et al. Decreased lipogenesis-promoting factors in adipose tissue in postmenopausal women with overweight on a Paleolithic-type diet. Eur J Nutr 2018; 57:2877-2886.

22. Jönsson T, Granfeldt Y, Ahrén B, Branell U, Pålsson G, Hansson AC, et al. Beneficial effects of a Paleolithic diet on cardiovascular risk factors in type 2 diabetes: a randomized cross-over pilot study. Cardiovasc Diabetol 2009;8:35.

23. Masharani U, Sherchan P, Schloetter M, Stratford S, Xiao A, Sebastian A, et al. Metabolic and physiologic effects from consuming a hunter-gatherer (Paleolithic)type diet in type 2 diabetes. Eur J Clin Nutr 2015;69(8):944-8. 
24. Osterdahl M, Kocturk T, Koochek A, Wandell PE. Effects of a short-term intervention with a Paleolithic diet in healthy volunteers. Eur J Clin Nutr 2008; 62(5):682-5.

25. Ryberg M, Sandberg S, Mellberg C, Stegle O, Lindahl B, Larsson C, et al. A Palaeolithic-type diet causes strong tissue-specific effects on ectopic fat deposition in obese postmenopausal women. J Intern Med 2013;274(1):67-76.

26. Lindeberg S, Jönsson T, Granfeldt Y, Borgstrand E, Soffman J, Sjöström K, A hrén B. A Palaeolithic diet improves glucose tolerance more than a Mediterranean-like diet in individuals with ischaemic heart disease. Diabetologia 2007; 50:1795-1807.

27. Boraxbekk CJ, Stomby A, Ryberg M, Lindahl B, Larsson C, Nyberg L, Olsson T. Diet-Induced Weight Loss Alters Functional Brain Responses during an Episodic Memory Task. Obes Facts 2015; 8:261-272.

28. Frassetto LA, Schloetter M, Mietus-Synder M, Morris RC, Sebastian A. Metabolic and physiologic improvements from consuming a paleolithic, hunter-gatherer type diet. Eur J Clin Nutr 2009;63(8):947-55.

29. Bligh HFJ, Godsland IF, Frost G, Hunter KJ, Murray P, Macaulay K, et al. Plantrich mixed meals based on Palaeolithic diet principles have a dramatic impact on incretin, peptide YY and satiety response, but show little effect on glucose and insulin homeostasis: an acute-effects randomised study. Br J Nutr 2015;113(4):574-84.

30. Markofski MM, Dolan CT, Davies NA, Ryan EJ, Carrillo AE. BDNF decreases in response to an 8-week "Paleo" diet intervention. Brain Behav Immun 2017; 66: 38.

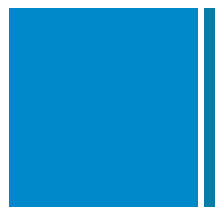

Corresponding author

Nara de Andrade Parente

Washington Soares Avenue, 1321 - Edson Queiroz -

Zip postal: 60811-905 - Fortaleza-CE, Brazil

Nutrition course

Email: naradeandrade@gmail.com 